\title{
Hadis tentang Uang: Analisis Syarah terhadap Nilai Uang dalam Perspektif Ekonomi Islam
}

\author{
Muhammad Tsani Abdillah \\ Jurusan Ilmu Hadis \\ Fakultas Ushuluddin UIN Sunan Gunung Djati Bandung, Indonesia \\ sanipintar088@gmail.com
}

\begin{abstract}
This study aims to discuss the understanding of hadith about the value of money in the perspective of Islamic economics. This research applies a qualitative type through literature study using thematic, takhrij, and syarah hadith methods as well as descriptive analysis. The discussion of this research includes an overview of money, thematic hadiths regarding money, and an understanding of the hadith about the value of money from an Islamic economic perspective in the contemporary era. This study concludes that the money used by Muslims at the time of the Prophet was Persian silver dirhams and Roman gold dinars, traditions about money are known to be maqbul traditions and can be used as evidence, and the understanding of hadiths about the value of money is closely related to buying and selling and selling. an effective prohibition of usury for controlling inflation so that people's purchasing power is maintained and economic stability is created, in this case Islamic economics which emphasizes increasing people's welfare is recognized in this contemporary era dealing with money politics with the ideology of capitalism.
\end{abstract}

Keywords: Economy, Hadith, Islam, Money, Syarah.

\begin{abstract}
Abstrak
Penelitian ini bertujuan membahas pemahaman hadis tentang nilai uang dalam perspektif ekonomi Islam. Penelitian ini menerapkan jenis kualitatif melalui studi pustaka dengan menggunakan metode tematik, takhrij, dan syarah hadis serta analisis deskriptif. Pembahasan penelitian ini meliputi tinjauan umum tentang uang, tematik hadis-hadis berkenaan dengan uang, dan pemahaman hadis tentang nilai uang perspektif ekonomi Islam di era kontemporer. Penelitian ini menyimpulkan bahwa uang yang digunakan oleh umat Islam pada masa Rasulullah adalah dirham perak Persia dan dinar
\end{abstract}


emas Romawi, hadis-hadis tentang uang diketahui merupakan hadis maqbul dan dapat dijadikan hujjah, dan pemahaman hadis-hadis tentang nilai uang berkenaan erat dengan jual beli dan larangan riba yang efektif bagi pengendalian inflasi sehingga daya beli masyarakat terjaga dan stabilitas perekonomian tercipta, dalam hal ini ekonomi Islam yang lebih menekankan peningkatan kesejahteraan masyarakat diakui pada era kontemporer ini berhadapan dengan politik uang ideologi kapitalisme.

Kata kunci: Ekonomi, Hadis, Islam, Syarah, Uang.

\section{Pendahuluan}

Uang merupakan konsep abstrak yang mudah ditunjukkan bentuknya sebagaimana dapat dilihat dalam wujud kehidupan sehari-hari, tetapi apa yang dipahami dengan uang terasa pelik dijelaskan nilainya. Penjelasan nilai uang dirasakan sangat dibutuhkan untuk menemukan pemahaman yang konkrit tentang konsep uang dalam pelaksanaan kehidupan ekonomi Islam. Sehingga melalui penjelasan tersebut konsep uang yang semula abstrak nilainya menjadi dapat dipahami secara konkrit. Uang menjadi subjek yang sentral dalam kehidupan mengingat perekonomian tidak lepas dari peran uang (Ilyas, 2017). Telah dipahami bersama bahwa kehidupan tidak terlepas dari perekonomian. Tentunya, uang memegang peranan yang sangat penting dalam segala aktivitas sosial dalam kehidupan ekonomi yang semakin modern saat ini. Uang menjadi subjek yang penting, bahkan uang merupakan salah satu penentu perkembangan ekonomi suatu negara. Uang dipakai untuk kebutuhan sehari-hari dan menjadi syarat yang diperlukan untuk mendorong perekonomian di suatu negara.

Uang awalnya hanya dipakai sebagai alat tukar menurut catatan sejarah kehidupan ekonomi, kini menjadi multi fungsi. Jauh sebelum negara-negara Barat menggunakan uang dalam kegiatan ekonomi apa pun, Islam sudah mengetahui alat tukar dan pengukuran nilai ini, dan bahkan Alquran dan hadis dengan jelas menunjukkan bahwa alat untuk mengukur nilai adalah emas dan perak. Para ulama menggunakan istilah emas dan perak dalam bahasa Arab dengan kalimat dinar dan dirham. Sebelum manusia menemukan mata uang sebagai alat tukar, perekonomian dilaksanakan dengan cara barter sebagai suatu praktik saling tukarmenukar antara barang dengan barang ataupun barang dengan jasa (Ilyas, 2017).

Setiap manusia membutuhkan kehidupan ekonomi untuk kelangsungan hidup dan karenanya pasti mereka setiap saat bersentuhan 
dengan nilai uang. Pada saat yang sama, segala praktik kehidupan umat muslim haruslah memiliki dasar normatif dari ajaran Islam, termasuk dalam kehidupan ekonomi, dan karenanya pula sangat dibutuhkan pemahaman nilai uang menurut pemahaman dan pandangan Islam sebagaimana yang pernah diajarkan dan dipraktikan oleh Rasulullah Saw. Pemahaman hadis tentang nilai uang dirasakan cukup mendesak terutama bila dihadapkan dengan sistem ekonomi konvesional dan kapitalis yang sedang menguasai perekonomian dunia pada saat ini (Faridha, 2011).

Sejumlah peneliti telah melakukan pengakajian seputar uang sebagaimana dalam tinjauan pustaka ini. Antara lain oleh Siti Mujibatun (2012) yang berjudul "Konsep Uang dalam Hadis," Tesis IAIN Walisongo Semarang, tahun 2012. Penelitian ini berangkat dari kegalauan dalam transaksi bisnis ekonomi syariah. Penelitian ini menggunakan studi pustaka dan sekaligus lapangan terhadap praktik ekonomi syariah. Penelitian ini menyimpulkan bahwa Rasulullah Saw telah mencontohkan praktik kehidupan ekonomi termasuk pemanfaatan nilai uang (Siti M. , 2012). Artikel jurnal Rahmat Ilyas (2017), judul "Konsep Uang dalam Perspektif Ekonomi Islam," IAIN Kudus: Jurnal Bisnis dan Management Islam. Artikel ini menggunakan pendekatan ekonomi Islam yang merupakan jenis kualitatif. Artikel ini menyimpulkan bahwa terdapat analisis untuk mengukur kegunaan barang alat tukar dan satuan uang dalam ekonomi Islam (Ilyas, 2017). Artikel jurnal Leni Saleh (2016), judul "Perubahan Nilai Tukar Uang dalam Perspektif Ekonomi Islam," IAIN Kediri: Jurnal Study Ekonomi dan Bisnis Islam. Pembahasan artikel penelitian ini mencakup tentang bagaimana nilai tukar uang dan implikasi terjadinya perubahan uang (Leni, 2016). Artikel jurnal Misbahul Munir (2016), judul "Implementasi Integrasi al-Qur'an dan Hadis: Analisis Tematik terhadap Konsep Uang dalam Islam," UIN Malang: Jurnal Research. Pembahasan penelitian ini mengkaji tentang konsep uang dalam perspektif Islam dengan menggunakan pendekatan integratif yang digali dari nilai-nilai al-Qur'an dan Sunnah (Misbahul, 2016). Artikel Jurnal Hanin Fadilla (2019), judul "Sejarah Penggunaan Uang sejak Masa Rasulullah Saw sampai Sekarang," STEBIS IGM Palembang: Jurnal Pemikiran dan Pengembangan Perbankan Syariah. Penelitian ini menunjukan bahwa pertukaran uang emas dan perak (dinar dan dirham) sudah dilakukan pada masa Rasulullah Saw. Hal ini berlanjut sampai pada masa Khalifah dan Bani Umayyah dan Abbasiyah. Penelitian ini menggunakan pendekatan library research (Fadilla, 2019).

Berbagai penelitian terdahulu bermanfaat bagi penyusunan kerangka berpikir penelitian ini. Uang dapat dikatakan nuqud atau tsaman (Ichsan, 2020). Uang menurut pandangan Islam merupakan alat tukar atau transaksi, alat untuk mendorong transaksi ekonomi (Andri, 2009). Maknanya memiliki banyak arti yaitu al-naqdu artinya lebih berguna 
ketimbang dirham, memegang dirham, al-naqdu bermakna juga uang kas (Ichsan, 2020). Bicara tentang nuqud tidak ditemukan pada al-Quran maupun hadis, sebab orang Arab umumnya tidak memakai nuqud buat membuktikan nilai harga (Rozalinda, 2014). Menurut definisi Abu Ubaid (wafat pada $224 \mathrm{H}$.), baik dirham maupun dinar yaitu kadar harga komoditas, dan tidak ada lagi selain itu, sehingga baik dinar maupun dirham yaitu ukuran normal pembayaran ketika negosiasi barang maupun jasa (Hasan, 2005). Terdapat 107 matan hadis yang menyinggung tentang jual beli emas, dirham (uang perak), dinar (uang emas), perak dan juga wariq dalam Kutub at-Tis'ah sebagian besar disandarkan kepada Nabi Saw secara marfu' (Mujibatun, 2012). Syarah hadis dilakukan dalam memberikan penjelasan mengenai hadis tentang nilai tukar uang. Syarah merupakan uraian terhadap materi tertentu, lengkap dengan unsur-unsur dan segala syarat yang berkaitan dengan objek pembahasan. Hal ini dilakukan untuk memberikan pemahaman dan penanggulangan mengenai nilai tukar uang dalam perspektif hadis (Suryadialaga, 2012). Para ulama telah menuliskan syarah pada kitab-kitab pemahaman nilai uang dari perspektif hadis (Al-Mubarakfuri, 1967). Nabi Muhammad Saw tidak tahu mencetak uang untuk umat Islam, karena beliau membenarkan dan menerapkan mata uang dinar dan dirham yang berlaku di kalangan orang Arab, tetapi kebanyakan alim ulama percaya bahwa dinar dan dirham adalah mata uang menurut syariah Islam (naqd syar'i). Mata uang adalah nilai atau harga barang (tsaman) (Al-Qattan, 2005). Hadis memberikan konsep uang (Mujibatun, 2012). Yakni flow concept dan public goods dalam perekonomian Islam (Karim A. A., 2001). Jika uang diandaikan seperti air, maka air (uang) tentu bersih dan sehat bagi perekonomian. Sebaliknya, jika meninggalkan air di suatu tempat (menumpuk uang), air (uang) hendak menjadi ternoda (Bustaman, 2016). Islam menganut flow concept yang mengalir bukan stock concept sebagai kepemilikan perorangan (Ilyas, 2016). Semakin cepat peredaran uangnya, semakin baik (Prasetyo, 2017). Uang yang beredar digunakan untuk menciptakan kemakmuran ekonomi dan kesehatan masyarakat (Latifah, 2015). Pada saat yang sama, jika menimbun uang, dapat menyebabkan macetnya perekonomian, yang menyebabkan krisis ekonomi (Anita, 2013). Para ahli ekonomi Islam mengakui manfaat mata uang sebagai alat tukar (Faridha, 2011). Nabi Muhammad sendiri lebih suka menggunakan mata uang daripada menukar barang dengan barang (Juliana, 2017). Riba al-fadl dilarang dalam Islam (Budiantoro, Sasmita, \& Widiastuti, 2018). Adalah sebuah langkah menuju ekonomi, mata uang juga merupakan transaksi barter menjadi wajar dan bebas dari ketidakadilan dan eksploitasi (Ayub, 2009).

Berdasarkan paparan di atas, formula penelitian disusun, yaitu rumusan masalah, pertanyaan utama penelitian, dan tujuan penelitian. Rumusan penelitian ini adalah terdapat pemahaman hadis tentang nilai 
uang dalam perspektif ekonomi Islam. Pertanyaan penelitiannya ialah bagaimana tinjauan umum tentang uang, bagaimana tema-tema hadis tentang uang, dan bagaimana pemahaman hadis tentang nilai uang perspektif ekonomi Islam. Tujuan penelitian ini yakni membahas hadis tentang nilai uang pada masa Rasulullah Saw. Diharapkan penelitian ini dapat bermanfaat untuk kontribusi pengetahuan dan pemahaman hadis.

\section{Metode Penelitian}

Penelitian ini menggunakan jenis kualitatif melalui studi kepustakaan (Darmalaksana, 2020). Yaitu data penelitian ini bukan merupakan angkaangka, melainkan data kualitatif yang diambil dari sumber primer dan sumber sekunder. Data tersebut berbentuk uraian yang dikaitkan dengan data lainnya yang memiliki kesamaan agar didapatkan kejelasan akan suatu kebenaran (Irawan \& Dkk, 2009).

Penelitian ini menerapkan beberapa metode. Antara lain metode tematik (Yamani, 2015) yang digunakan untuk menghimpun hadis terkait dengan uang dari kitab-kitab hadis (Misbahul, 2016). Penelitian ini juga menerapkan metode takhrij untuk melakukan tinjauan status hadis (Soetari, 2015). Digunakan pula dalam penelitian metode syarah hadis dalam upaya menemukan pemhaman terhadap hadis (Darmalaksana, 2020). Secara umum, penelitian ini dapat dipahami sebagai analisisdeskriptif (Sukardi, 2011).

\section{Hasil dan Pembahasan}

Hasil dan pembahasan penelitian di bawah ini.

\section{Tinjauan Umum tentang Uang}

Bagian ini membahas pengertian uang, sejarah uang, dan nilai tukar uang.

\section{a) Pengertian Uang}

Penyebutan uang dalam istilah Arab biasa disebut dengan kata nuqud atau fulus, dan uang sendiri bisa berbentuk kertas ataupun logam yang kemudian dikeluarkan oleh suatu lembaga yang memiliki wewenang untuk menerbikannya (mencetak dan memasarkan). Atas dasar definisi ini M. Rawwas Qal'ah berpendapat bahwa seandainya masyarakat dalam melakukan transaksi menggunakan unta sebagai alat pembayaran, maka unta tersebut tidak dapat dipandang sebagai uang (nuqud) melainkan hanya sebagai badal (pengganti) atau 'iwadh (imbalan). Hal itu karena sesuatu yang dipandang sebagai uang harus memenuhi sekurangkurangnya dua syarat, pertama, substansi benda tersebut tidak bisa dimanfaatkan secara langsung melainkan hanya sebagai media untuk memperoleh manfaat, kedua, dikeluarkan oleh lembaga yang memiliki otoritas untuk menerbitkan uang seperti bank sentral (Ichsan, 2020). 
Jika dicermati secara seksama, di dalam al-Qur'an dan hadis tidak ditemukan penyebutan kata nuqud (uang). Masyarakat Arab pada masa itu lebih menggunakan istilah dinar, dirham atau wariq ketika melakukan transaksi ataupun ketika menanyakan nilai harga suatu barang dan lain sebagainya. Adapun penggunaan kata fulus (mata uang tembaga) mereka gunakan ketika hendak menanyakan berang-barang dengan nilai harga yang relatif rendah, karna kedudukan fulus sendiri di bawah dinar, dirham dan wariq. Uang yang digunakan oleh umat Islam pada masa Rasulullah adalah dirham perak Persia dan dinar emas Romawi dalam bentuk aslinya, tanpa mengalami pengubahan atau pemberian tanda tertentu. Rasulullah pun tidak pernah membuat uang khusus untuk umat Islam. Dengan kata lain, pada masa itu belum ada apa yang disebut dengan "uang Islam" (Rozalinda, 2014).

Abu Ubaidah (wafat 224 H.) menuturkan bahwasannya nuqud (dinar, dirham) sebagai alat untuk mengukur nilai atau harga sesuatu, akan tetapi sesuatu tersebut tidak bisa menjadi harga untuk kedua benda tersebut (dinar, dirham), maka dalam hal ini dapat dipahami bahwasannya kedua benda tersebut merupakan standarisasi (ukuran) dalam suatu transaksi yang meliputi barang ataupun jasa. Sedangkan al-Ghazali (wafat 505 H.) mengemukakan, bahwasannya Allah menciptakan bagi manusia dinar dan dirham yang berfungsi sebagai penentu (hakim) bagi seluruh harta benda dan seluruh harta benda dapat diukur menggunakan keduanya. Sedangkan Ibnu Qayyim (wafat 751 H.) mengemukakan bahwasannya dinar dan dirham merupakan nilai harga suatu barang yang relatif mudah untuk diperdagangkan, dapat diserahkan secara fisik (komuditas). Dari pemaparan di atas maka uang merupakan suatu standarisasi alat ukur terhadap suatu barang (Hasan, 2005).

Definisi lain menyatakan bahwasannya uang merupakan standar kegunaan yang dapat digunakan oleh seseorang terhadap suatu barang atau jasa. Akan tetapi, uang lebih digunakan sebagai alat ukur bagi barang atau benda saja dan untuk jasa lebih kepada penggunaan upah untuk standar jasa manusia (An-Nabhani, 2000).

Menurut Ibnu Taymiyah, uang dalam Islam adalah sebagai alat tukar dan alat ukur nilai. Jika di dalam nilai tukar uang itu berubah, maka harus disesuaikan dengan kondisi yang telah ada. Melalui perubahan nilai tukar itulah, nilai suatu barang akan diketahui (Karim A. , 2005). Dalam pandangan al-Ghazali uang merupakan suatu karunia yang Allah berikan kepada manusia yang dengannya manusia dapat menggunakannya sebagai alat untuk mendapatkan berbagai macam kebutuhan hidup baik secara manfaat atau secara subtansinya, dan uang juga merupakan sesuatu yang sangat dibutuhkan manusia sebagai alat tukar (Dimyati, 2008). Pendapat lain juga menyatakan uang itu ibarat sebuah kaca, kita ketahui bahwasannya kaca tidak memiliki warna, akan tetapi kaca dapat 
mereflekaikan semua warna. Begitu juga uang, uang tidak memiliki harga tetapi uang sendiri dapat mereflekasikan semua harga. Jika melihat kepada fungsi dari uang tersebut dapat dipahami bahwasannya uang sebagai alat yang dapat memberikan asas kegunaan dan kepuasan bagi pemiliknya.

\section{b) Sejarah Uang}

Bangsa Arab Hijaz di zaman Jahiliah belum memiliki mata uang sendiri. Mereka menggunakan dinar hercules, Byziantum dan dirham sasanid yang diperoleh dari Irak, bagian dari mata uang Himyar, Yaman. Orangorang Makkah tidak berdagang kecuali mereka memperlakukannya sebagai emas murni dan tidak menerima emas dalam skala besar. Hal ini disebabkan bentuk dan ukuran dirham yang berbeda, dan perilaku penipuan terjadi dalam bentuk mata uang karena nilai penawaran melebihi nilai sebenarnya.

Sejarah Islam mencatat pada masa Rasulullah mata uang menggunakan standar emas dan perak. Hal ini juga terjadi pada masa-masa setelah masa Rasulullah, seperti masas khulafah al-Rasyidin, Umayyah dan Abbasiyah. Bagi kacamata Islam, mata uang yang paling stabil yang tidak dapat menyebabkan krisis moneter merupakan mata uang dinar, dirham. Karna nilai intrinsiknya sama dengan nilai riilnya. Mata uang tersebut juga telah ada jauh-jauh hari sebelum kedatangan Islam. Dalam hal ini, Nabi Muhammad pada saat itu memerintahkan bagi masyarakat Madinah untuk menyesuaikan ukuran timbangan (kadar) para penduduk Makkah ketika terjadi sebuah transaksi mu'amalah dan alat tukar (uang) menggunakan dua logam mulia dinar dan dirham (Mujahidin, 2007).

Di masa pemerintahan Umar ibn Khatab, yaitu masa-masa kejayaan Islam, ia belum juga berkesempatan untuk melakukan perubahan dalam hal mata uang dikarenakan oleh kesibukan pemerintah (memperluas wilayah kekuasaan Islam). Akan tetapi, pada tahun $18 \mathrm{H}$. barulah Islam memiliki mata uang sendiri, namun masih tetap mengikuti model cetakan sasanid berukiran kisra dengan tambahan kalimat tauhid, Muhammad Rasul Allah di dalamnya. Pada masa Umar juga sempat terbesit untuk mencetak uang dari kulit unta, akan tetapi niat tersebut dibatalkannya dikarenakan melihat kepada akibat di kedepannya. Salah satu akibat terbesar jika terwujudnya uang dari kulit unta maka di kemudian hari akan terjadi kelangkaan terhadap binatang ini. Setelah wafatnya Umar, pencetakan uang seperti ini (menggunakan dirham dan ninar) dilanjutkan oleh khalifah-khalifah selanjutnya dan terukir di dalamnya kalimat-kalimat takbir, basmalah, dan lain sebagainya (Rozalinda, 2014).

Selanjutnya pada masa kekhalifahan Abdul Malik bin Marwan barulah dilakukan pencetakan uang dengan model tersendiri dan tidak terdapat model-model ataupun lambang-lambang Bizantium atau Persia di dalamnya. Adapun dinar yang dicetak merupakan bentuk emas dengan 22 
karat sedangkan dirham dengan 15 karat. Ternyata hal yang dilakukan sang khalifah ini dapat meningkatkan kondisi ekonomi dan pemerintahan dan dapat mengurangi pemalsuan terhadap uang. Hal yang dilakukan khalifah Abdul Malik ini kemudain dilanjutkan oleh dua khalifah sesudahnya yaitu Yazid bin Abdul Malik dan Hisyam bin Abdul Malik. Keadaan seperti ini terus berjalan hingga masuk ke fase pemerintahan bani Abasiyyah yang tetap mengikuti dinar dirham masa dinasti Umayyah. Akan tetapi pada masa ini terjadi sedikit perubahan pada ukiran dinar dan dirhamnya.

Pada masa dinasti Abbasiah ini terjadi penurunan nilai uang, dikarenakan dalam peroses pembuatannya dicampur dengan bahan tembaga. Hal ini dilakukan oleh mereka (para penguasa) untuk meraup keuntungan dari pencetakan uang tersebut. Hal seperti ini berakibat terjadinya inflasi, harga barang melambung tinggi walau masyarakat tetap menggunakan dinar dan dirham. Kondisi ini terus berlanjut hingga masa pemerintahan dinasti Fatimiyah. Adapun perbandingan antara dinar dan dirham pada masa itu ialah $1: 34$, padahal sebelumnya $1: 10$ (Susanti, 2017).

Selanjutnya, pada masa kekhalifahan dinasti Utsmaniah (1534 M.) uang yang diedarkan secara resmi tetap menggunakan emas dan perak dengan nilai mata uang 1.15. Kemudain pada tahun 1839 barulah pemerintah Utsmaniah menerbitkan mata uang dalam bentuk kertas (Rozalinda, 2014).

\section{c) Nilai Tukar Uang}

Perubahan nilai tukar uang dalam Islam dapat dibenarkan jika dalam prosesnya (pertukarannya) tersebut tidak mengandung unsur riba atau bunga. Dalam hal ini, pertukaran mata uang bisa terjadi jika uang tersebut jelas, kontan dan bukan dengan cara kredit. Jika hal itu dapat dipenuhi, maka dapat dibenarkan sepanjang hal tersebut tidak mengandung unsur riba atau bunga (An- Nabhani, 1999).

Istilah nilai tukar biasa disebut kurs. Kurs adalah perbandingan nilai tukar uang suatu negara dengan mata uang negara asing atau perbandingan nilai tukar valuta antar negara. Pengukuran nilai atau nilai tukar dipengaruhi oleh besarnya volume perdagangan negara tersebut. Pengukuran nilai kurs ini secara umum dipengaruhi oleh perubahan tingkat harga yang berlaku pada suatu negara dibandingkan perubahan tingkat harga pada negara partnernya. Nilai kurs semacam ini dikenal sebagai kurs efektif. Kurs atau nilai tukar adalah sesuatu yang penting karena perdagangan internasional (ekspor impor) dapat dilakukan. Pembayaran transaksi komersial dan finansial antar negara dapat terlaksana. Kerjasama lalu lintas pembayaran (LLP) antar bank devisa dunia dapat terlaksana. Transaksi jual beli valuta asing (valas) dapat dilakukan. Orang dapat bepergian antar negara (Hasibun, 2001). 
Ekonomi Islam menggunakan sharf sebagai suatu aktivitas pertukaran mata uang dan aktifitas ini merupakan hal yang diperbolehkan (mubah). Sharf sendiri merupakan upaya penukaran atau jual beli mata uang dengan mata uang asing, seperti pertukaran mata uang rupiah dengan ringgit atau dolar (Arifin, 2003).

Apabila aktivitas pertukaran tersebut sempurna, kemudian salah seorang di antara mereka ingin menarik kembali, maka tindakan semacam ini tidak diperbolehkan bila akad dan penyerahannya sudah sempurna. Kecuali di sana terjadi penipuan yang keji (ghabu fasihy), atau cacat maka boleh. Nilai tukar kurs dapat berubah dari waktu ke waktu sebagai akibat perubahan nilai atau dinamakan perubahan harga relatif (merujuk pada inflasi berarti harga nominal atau perubahan dari seluruh harga, sedangkan perubahan harga relatif tidak semua harga barang berubah). Dalam hal ini berada pada tingkat harga yang naik cepat, naik lebih lambat bahkan ada yang turun. Ilustrasi kurs dapat berubah karena perubahan harga relatif. Jadi dapat dikatakan perubahan tingkat harga maupun kurs dipengaruhi oleh banyak faktor (An- Nabhani, 1999).

Berkaitan dengan pertukaran mata uang, seseorang haruslah memenuhi syarat-syarat yang telah ditetapkan sebagaimana yang terdapat hadis atau dalil yang membolehkan pertukaran tersebut: "Juallah emas dengan perak sesuka kalian, dengan (syarat harus) kontan" (HR. Imam atTirmidzi, dari Ubadah bin Shamit).

Dari dalil tersebut, maka syarat-syarat dari nilai tukar uang atau kurs antara lain: a) Harus tunai, tidak dengan cara kredit; b) Serah terima harus dilaksanakan dalam majelis kontak; dan c) Bila dipertukarkan mata uang yang sama harus dalam jumlah atau kuantitas yang sama. Tapi jika dalam pertukaran antara dua jenis mata uang hanya diisyaratkan kontan dan barangnya sama-sama ada.

Implikasi terjadinya perubahan nilai tukar uang bukan saja berdampak pada tingkat barang domestik tetapi juga berdampak pada tingkat harga dari mata uang suatu negara. Jika pemerintah mengalami anggaran defisit maka tabungan domestik menurun. Pengaruh perubahan ini menunjukkan penawaran rupiah menjadi berkurang sehingga nilai rupiah menjadi naik (more valuable) nilai tukar riil akan mengalami kenaikan. Karena nilai rupiah meningkat maka harga barang domestik relatif menjadi mahal dibandingkan harga barang luar. Selanjutnya nilai ekspor akan menurun dan atau nilai impor akan meningkat sehingga net ekspor akan mengalami defisit (Arifin, 2003).

\section{Tema-tema Hadis tentang Uang}

Sebagai sumber hukum kedua setelah al-Qur'an, hadis mempunyai isi kandungan yang komprehensif mencakup informasi dalam menghadapi permasalaham di segala zaman begitupula mengenai informasi tentang 
uang yang sudah diinformasikan oleh hadis Rasulullah SAW sebagai berikut:

Tabel 1. Tema-tema Hadis tentang Uang

\begin{tabular}{|c|c|c|c|}
\hline No. & Redaksi Matan Hadis & Tema & Nomor Hadis \\
\hline 1 & $\begin{array}{l}\text { Telah menceritakan kepada } \\
\text { kami Shadaqah bin al-Fadhal } \\
\text { telah mengabarkan kepada } \\
\text { kami Isma'il bin 'Ulayyah } \\
\text { berkata, telah menceritakan } \\
\text { kepada saya Yahya bin Abu } \\
\text { Ishaq telah menceritakan } \\
\text { kepada kami 'Abdurrahman } \\
\text { bin Abu Bakrah berkata, Abu } \\
\text { Bakrah radhiallahu'anhu } \\
\text { berkata; Telah bersabda } \\
\text { Rasulullah } \\
\text { kalian berjual beli emas } \\
\text { dengan emas kecuali dengan } \\
\text { jumlah yang sama, perak } \\
\text { dengan perak kecuali dengan } \\
\text { jumlah yang sama dan berjual } \\
\text { belilah emas dengan perak } \\
\text { atau perak dengan emas } \\
\text { sesuai keinginan kalian." }\end{array}$ & Jual beli & $\begin{array}{l}\text { Shahih Bukhari } \\
\text { No. } 2029\end{array}$ \\
\hline 2 & $\begin{array}{l}\text { Telah mengabarkan kepada } \\
\text { kami Ishaq bin Ibrahim, ia } \\
\text { berkata; telah menceritakan } \\
\text { kepada kami Sufyan dari az- } \\
\text { Zuhri dari Malik bin Aus bin } \\
\text { al-Hadatsan bahwa Ia } \\
\text { mendengar Umar bin al- } \\
\text { Khathab berkata; Rasulullah } \\
\text { dengan perak adalah riba, } \\
\text { kecuali serah terima secara } \\
\text { langsung, kurma dengan } \\
\text { kurma adalah riba kecuali } \\
\text { serah terima secara langsung, } \\
\text { gandum dengan gandum } \\
\text { adalah riba kecuali serah } \\
\text { terima secara langsung, } \\
\text { jewawut dengan jewawut }\end{array}$ & Riba & $\begin{array}{l}\text { Sunan Nasa'i } \\
\text { No. } 4482\end{array}$ \\
\hline
\end{tabular}




\begin{tabular}{|l|l|l|l|}
\hline $\begin{array}{l}\text { adalah riba kecuali serah } \\
\text { terima secara langsung." }\end{array}$ & & \\
\hline
\end{tabular}

Tabel 1. menunjukan terdapat 2 (dua) hadis tentang uang yakni jual beli, dan riba. Data ini diperoleh melalui penelusuran dalam Kutub alTis'ah sebagai mashadir asliah. Hadis-hadis ini diklasifikasikan melalui pendekatan tematik. Teks hadis tersebut terdapat pada kitab Shahih Bukhari, dan Sunan Nasa'i matannya memuat tema-tema nilai tukar uang.

Tema-tema hadis menyangkut nilai tukar uang melalui penelusuran dengan metode tematik akan disajikan melalui metode takhrij dan syarah hadis sebagaimana sajian di bawah ini.

\section{a) Jual Beli}

Berikut redaksi hadis Rasulullah berkenaan dengan jual beli dengan jumlah yang sama jangan berlebihan.

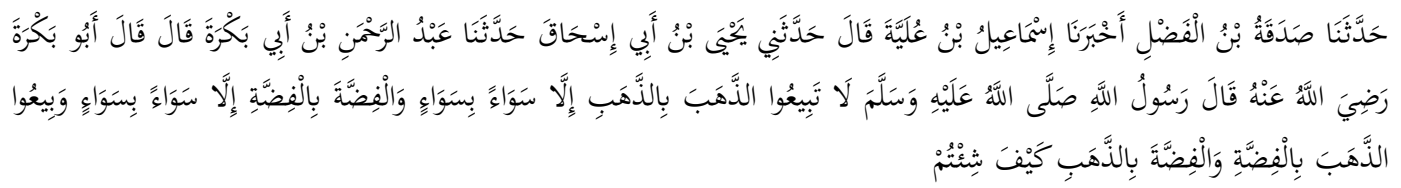

Telah menceritakan kepada kami Shadaqah bin al-Fadhal telah mengabarkan kepada kami Isma'il bin 'Ulayyah berkata, telah menceritakan kepada saya Yahya bin Abu Ishaq telah menceritakan kepada kami 'Abdurrahman bin Abu Bakrah berkata, Abu Bakrah radhiallahu'anhu berkata; Telah bersabda Rasulullah" Jangan kalian melakukan transaksi jual beli sesama emas melainkan dengan jumlah yang sepadan baik nilai atau takarannya, dan jangan pula melakukan transaksi perak dengan perak kecuali dengan nilai dan kadar yang sama dan lakukanlah transaksi jual beli baik itu emas dengan perak atau sebaliknya sesuai keinginan kalian" (Shahih Bukhari No. 2029).

Tabel 2. Daftar Rawi dan Sanad

\begin{tabular}{|c|c|c|c|c|c|}
\hline Nama & Kunyah & Kalangan & $\begin{array}{l}\text { Negeri } \\
\text { Hidup }\end{array}$ & $\begin{array}{l}\text { Tahun } \\
\text { Wafat }\end{array}$ & $\begin{array}{l}\text { Komentar } \\
\text { Ulama }\end{array}$ \\
\hline $\begin{array}{l}\text { Nufai' bin } \\
\text { al-harits bin } \\
\text { Kildah }\end{array}$ & Abu Bakar & $\begin{array}{l}\text { Tabi'in } \\
\text { kalangan } \\
\text { biasa }\end{array}$ & Bashrah & $52 \mathrm{H}$. & Shahabat \\
\hline $\begin{array}{l}\text { Abdur } \\
\text { Rahman bin } \\
\text { Abi Bakrah } \\
\text { Nufai' bin } \\
\text { al-Harits }\end{array}$ & Abu Bahar & $\begin{array}{l}\text { Tabi'in } \\
\text { kalangan tua }\end{array}$ & Bashrah & $96 \mathrm{H}$. & $\begin{array}{l}\text { Ibnu hibban } \\
\text { disebutkan } \\
\text { dalam ats- } \\
\text { tsiqaat }\end{array}$ \\
\hline
\end{tabular}




\begin{tabular}{|l|l|l|l|c|l|}
\hline $\begin{array}{l}\text { Yahya bin } \\
\text { Abi Ishaq }\end{array}$ & - & $\begin{array}{l}\text { Tabi'in } \\
\text { kalangan } \\
\text { biasa }\end{array}$ & Bashrah & $136 \mathrm{H}$. & $\begin{array}{l}\text { Yahya bin } \\
\text { Ma'in } \\
\text { berpendapat } \\
\text { bahwa beliau } \\
\text { tsiqat }\end{array}$ \\
\hline $\begin{array}{l}\text { Isma'il bin } \\
\text { Ibrahim bin } \\
\text { Muqsim }\end{array}$ & Abu Hisyir & $\begin{array}{l}\text { Tabiut } \\
\text { Tabi'in } \\
\text { kalangan } \\
\text { pertengahan }\end{array}$ & Bashrah & $193 \mathrm{H}$. & $\begin{array}{l}\text { Syu'bah } \\
\text { berpendapat } \\
\text { bahwa beliau } \\
\text { Sayyidul } \\
\text { Muhadditsin }\end{array}$ \\
\hline $\begin{array}{l}\text { Shidaqah } \\
\text { bin al- } \\
\text { Fadhol }\end{array}$ & $\begin{array}{l}\text { Abu al- } \\
\text { Fadhol }\end{array}$ & $\begin{array}{l}\text { Tabi'ul Atba } \\
\text { kalangan tua }\end{array}$ & Himsh & $223 \mathrm{H}$. & $\begin{array}{l}\text { Ibnu Hajar al- } \\
\text { Atsqalani } \\
\text { berpendapat } \\
\text { bahwa beliau } \\
\text { Tsiqah }\end{array}$ \\
\hline
\end{tabular}

Tabel 2. Hadis shahih Bukhari Nomor 2029, hal ini tentang jual beli dilihat dari proses tahammul wa al ada' yang menggunakan hadatsana, akhbarana dan sami'tu mengindikasikan bahwa mereka bertemu langsung. Hadis riwayat Bukhari ini muttasil (bersambung). Dan juga dilihat dari adanya hubungan antara guru dan murid pada masing-masing perawi dilihat dari negeri hidup dan tahun wafatnya yang sangat memungkinkan terjadinya pertemuan antara guru dan murid. Dan juga tidak terjadi keterputusan sanad (Wiyono, 2019). Para ulama juga menilai para periwayat adalah rawi yang tsiqah (adil dan dhabit) dan juga tidak ditemukan syadz dan illat. Jadi hadis tentang jual beli dengan jumlah yang sama jangan berlebihan adalah hadis yang maqbul dan bisa dijadikan hujjah.

Jual beli menurut hadis harus jujur, saling menguntungkan, berdasarkan atas pilihan sendiri, jelas barangnya, bukan milik orang lain, tidak boleh ada yang tertipu dan dirugikan, penjual dan pembeli samasama punya hak khiyar untuk mengurungkan kontrak bisnisnya atau meneruskan (Suqiyah, 2007).

\section{b) Riba}

Berikut redaksi hadis Rasulullah terkait tata cara jual beli yang benar untuk macam macam barang yaitu barang-barang yang padanya terkena hukum riba.

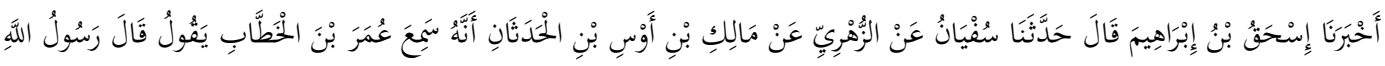

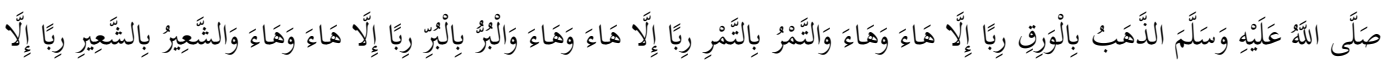

$$
\begin{aligned}
& \text { هَاءَ وَهَاءَ }
\end{aligned}
$$

Telah mengabarkan kepada kami Ishaq bin Ibrahim, ia berkata; telah menceritakan kepada kami Sufyan dari az-Zuhri dari Malik bin Aus bin al- 
Hadatsan bahwa Ia mendengar Umar bin al-Khathab berkata; Rasulullah bersabda, "Menjual emas dengan perak adalah riba, kecuali serah terima secara langsung, kurma dengan kurma adalah riba kecuali transaksinya secara langsung, gandum dengan gandum adalah riba kecuali transaksinya secara langsung, jewawut dengan jewawut adalah riba kecuali transaksinya secara langsung."

Tabel 3 Daftar Rawi Sanad

\begin{tabular}{|c|c|c|c|c|c|c|c|}
\hline \multirow[t]{2}{*}{ No. } & \multirow{2}{*}{ Rawi Sanad } & \multicolumn{2}{|c|}{ Lahir/Wafat } & \multirow[t]{2}{*}{ Negeri } & \multirow[t]{2}{*}{ Kuniyah } & $\begin{array}{l}\text { Komentar } \\
\text { Ulama }\end{array}$ & \multirow[t]{2}{*}{ Kalangan } \\
\hline & & L & $\mathbf{W}$ & & & \begin{tabular}{l|l}
- & +
\end{tabular} & \\
\hline 1 & $\begin{array}{l}\text { Umar bin } \\
\text { al- } \\
\text { Khaththab } \\
\text { bin Nufail }\end{array}$ & & $23 \mathrm{H}$. & Madinah & Abu Hafsh & Shahabat & Shahabat \\
\hline 2 & $\begin{array}{l}\text { Malik bin } \\
\text { Aus bin al- } \\
\text { Hadatsan }\end{array}$ & & $92 \mathrm{H}$. & Madinah & Abu Sa'id & $\begin{array}{l}\text {-ats } \\
\text { tsiqaat } \\
\text {-Lahu } \\
\text { Ru'yah }\end{array}$ & $\begin{array}{l}\text { Tabi'in } \\
\text { kalangan } \\
\text { tua }\end{array}$ \\
\hline 3 & $\begin{array}{l}\text { Muhammad } \\
\text { bin Muslim } \\
\text { bin } \\
\text { 'Ubaidillah } \\
\text { bin } \\
\text { 'Abdullah } \\
\text { bin Syihab }\end{array}$ & & $124 \mathrm{H}$. & Madinah & Abu Bakar & $\begin{array}{l}\text {-Faqih } \\
\text { hafidz } \\
\text { mutqin } \\
\text {-seorang } \\
\text { tokoh }\end{array}$ & $\begin{array}{l}\text { Tabi'ut } \\
\text { Tabi'in } \\
\text { kalangan } \\
\text { pertengahan }\end{array}$ \\
\hline 4 & $\begin{array}{l}\text { Sufyan bin } \\
\text { ‘Uyainah } \\
\text { bin } \\
\text { Abi'Imran } \\
\text { Maimun }\end{array}$ & & $198 \mathrm{H}$. & Kufah & $\begin{array}{l}\text { Abu } \\
\text { Muhammad }\end{array}$ & $\begin{array}{l}\text {-Hafidz } \\
\text { Mutqin } \\
\text {-Tsiqah } \\
\text { tsabat } \\
\text { dalam } \\
\text { hadis } \\
\text {-Ahadul } \\
\text { A'lam } \\
\text {-Tsiqah } \\
\text { tsabat } \\
\text {-Hafidz } \\
\text { Imam }\end{array}$ & $\begin{array}{l}\text { Tabi'ut } \\
\text { Tabi'in } \\
\text { kalangan } \\
\text { pertengahan }\end{array}$ \\
\hline 5 & $\begin{array}{l}\text { Ishaq bin } \\
\text { Ibrahim bin } \\
\text { Makhlad }\end{array}$ & & $238 \mathrm{H}$. & Himsh & Abu Ya'kub & $\begin{array}{l}\text {-Ahadul } \\
\text { Aimmah } \\
\text {-Ats } \\
\text { Tsiqah }\end{array}$ & $\begin{array}{l}\text { Tabi'ul } \\
\text { Atba' } \\
\text { kalangan } \\
\text { tua }\end{array}$ \\
\hline
\end{tabular}




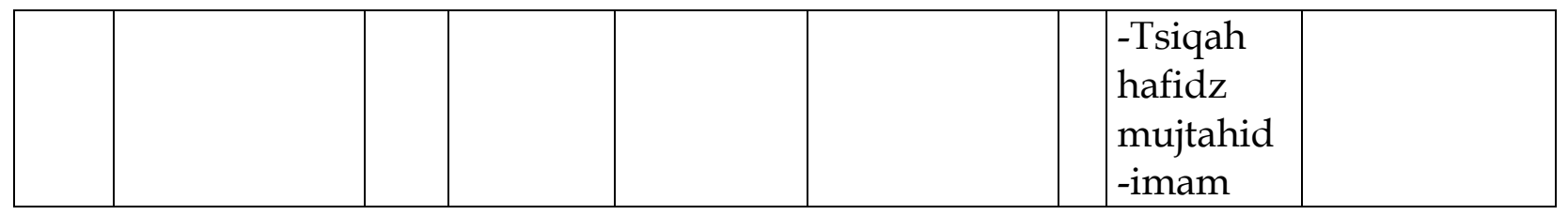

Tabel 3. Hadis Sunan an-Nasa'i Nomor 4482, hal ini dilihat dari proses tahammul wa al ada' menggunakan hadatsana, akhbarana dan sami'tu yang mengindikasikan bahwa mereka bertemu langsung (Qomarullah, 2016). Hadis riwayat an-Nasa'i ini muttasil (bersambung). Dan juga dilihat dari adanya hubungan antara guru dan murid pada masing-masing perawi dilihat dari negeri hidup dan tahun wafatnya yang sangat memungkinkan terjadinya pertemuan antara guru dan murid. Dan juga tidak terjadi keterputusan sanad (Sanusi, 2014). Hadis ini merupakan bagaimana gambaran pertukaran atau transaksi pada masa dahulu.

Terkait jual belinya disebutkan kata إلاهاءوهء yang memiliki banyak cara pengucapan. Yang paling terkenal adalah dengan memanjangkan (huruf ha') dan memfathahkan hamzah. Maknanya adalah tunai (Abdurrahman, 2010). Ini berarti dalam pembayarannya haruslah masih dalam keadaan bertatap muka antara penjual dan pembeli.

Hadis di atas menjelaskan tata cara jual beli yang benar untuk macam macam barang di atas yaitu barang-barang yang padanya terkena hukum riba. Caranya adalah orang yang hendak menjual emas dan perak atau sebaliknya harus dilakukan satu waktu dan kontan. Kalau tidak, maka akad jual beli tidak sah. Karena jual beli ini adalah tukar menukar dimana untuk sahnya disyaratkan dilakukan tunai.

Jika komoditi yang ditransaksikan meliputi emas, perak, gandum, gerst, kurma, dan garam, serta jenis komoditi lainnya yang semisal yang ditentukan dengan metode qiyas, maka transaksinya harus dilakukan secara langsung (dari person ke person), tidak boleh ditangguhkan, dan kadarnya harus sama (equal). Karena penangguhan penyerahan komoditi yang menyebabkan meningkatnya salah satu nilai tukar komoditi adalah termasuk riba (Abdullah, 2000).

Jika dipahami secara kontekstual, maksud hadis di atas adalah tukar menukar emas selama emas tersebut dijadikan barang maka tidak akan terkena hukum riba padanya. Jika dilihat dari sosio historis juga pada saat itu emas dan perak memanglah menjadi alat tukar dunia dan sekarang sudah beralih mengikuti zaman.

Islam memandang bahwa uang bukanlah komoditas (barang dagangan) melainkan alat pembayaran. Islam menolak keras segala jenis transaksi semu seperti yang terjadi di pasar uang atau pasar modal saat ini. Sebaliknya, Islam mendorong perdagangan internasional. Muhammad Saw, sebelum menjadi Rasul, telah menjadi pedagang internasional sejak usia remaja. Ketika berusia belasan tahun, beliau telah berdagang ke Syam 
(Suriah), Yaman dan beberapa negara di kawasan Teluk. Lalu saat beliau menjadi Rasul sekaligus menjadi kepala negara Daulah Islamiyah di Madinah, sejak awal kekuasaannya, umat Islam telah menjalin kontak bisnis dengan Cina, India, Persia dan Romawi. Bahkan hanya dua abad kemudian (abad kedelapan), para pedagang Islam telah mencapai Eropa Utara (Pertadireja, 1994).

Pelarangan riba merupakan upaya untuk mengendalikan inflasi, selanjutnya dengannya pula daya beli masyarakat tetap terjaga dan stabilitas ekonomipun tercapai. Bersamaan dengan itu, Islam mengarahkan para pemilik modal untuk melakukan kegiatan ekonomi yang lebih produktif seperti menggunakan sistem mudharabah (bagi hasil) muzara'ah dan musaqah. Dengan demikian terjadilah keselarasan antara sektor rill dan moneter sehingga pertumbuhan ekonomi dapat tumbuh secara berkesinambungan.

\section{Pemahaman Nilai Uang Perspektif Hadis di Era Kotemporer}

Bagian ini menyajikan pembahasan tentang uang menurut hadis, Nabi Saw teladan dalam bisnis, nilai uang dalam ekonomi Islam kontemporer, dan implikasi penelitian bagi kehidupan ekonomi masa kini.

\section{a) Uang menurut Hadis}

Penggunaan uang emas sebagai alat bayar bukan tanpa alasan syar'i, karena menurut referensi dari kitab hadis ternyata terdapat matan-matan hadis yang membicarakan tentang uang emas dan sejenisnya. Banyak hadis yang mengatur hukum transaksi emas, misalnya dalam kitab hadis sembilan (Kutub at-Tis'ah), terdapat kurang lebih 107 matan hadis yang menyinggung tentang jual beli emas, dirham (uang perak), dinar (uang emas), perak dan juga wariq (uang perak), sehingga para uama hadis memahami uang berasal dari hal tersebut sebagai mata uang sejenis yaitu emas dengan istilah dan ukuran yang berbeda (Siti M. , 2012). Berdasarkan uraian di atas bahwa uang yang digunakan oleh umat Islam pada masa Nabi Saw adalah dirham (uang perak) Persia dan dinar (uang emas) Romawi dalam bentuk aslinya, tanpa mengalami pengubahan atau pemberian tanda tertentu.

\section{b) Nabi Muhammad Saw. Teladan Bisnis}

Rasulullah adalah kiblat bagi umat untuk diteladani dalam segala aspek. Tak terkecuali terkait kepemimpinan beliau dalam hal bisnis. Rasulullah merupakan panutan berkenaan dengan nilai kepemimpinan bisnis (business leadership values).

Salah satu nilai yang bisa dicermati dari Rasulullah dalam bidang bisnis adalah jiwa kewirausahaan beliau. Jiwa bisnis ini beliau pupuk mulai dari umur 8 (delapan) tahun, persisnya saat Rasulullah menempa kemandirian dengan menggembala kambing hingga menginjak usia 12 
tahun. Setelahnya Rasululah mulai berdagang bukan hanya lintas daerah tetapi juga merambah ke lintas negara.

Pada usia 12 tahun, Rasulullah memulai mengikuti perniagaan kafilah sebagai pedagang menuju ke Syiria, hingga hampir 13 tahun lamanya. Saat berumur 25 tahun, beliau sudah melakukan perjalanan dagang luar negeri hingga 18 kali. Mulai dari Lebanon, Yaman, hingga Jorash. Perjalanan bisnis Rasulullah ini yang menghasilkan keuntungan besar, sehingga menjadikan beliau sebagai eksekutif muda tersohor di zamannya.

Sebagai pengelola bisnis yang andal, Rasulullah membangun aliansi strategis (strategic alliance) dalam praktik bisnis. Beliau berpartner dengan Siti Khadijah, seorang investor yang tersohor kaya dan sudah terbukti sukses menjadi investor dengan membiayai serombongan kafilah untuk berdagang ke luar negara dengan mendapatkan imbal hasil yang tinggi (Abdulloh, Rich, \& Laode , 2011).

\section{c) Nilai Uang dalam Ekonomi Islam Kontemporer}

Berkenaan dengan jual beli emas secara tidak tunai para ulama dalam hal ini terbagi ke dalam beberapa pendapat. Sebagian mengemukakan bahwasannya terlarang, ini merupakan salah satu pendapat mayoritas para ulama. Sedangkan yang membolehkan seperti Ibnu Taimiyah, Ibnu Qayyim dan beberapa ulama dari kalangan kontemporer.

Ibnu Taimiyah berpendapat, "diperbolehkan melakukan jual beli perhiasan emas dan perak dengan jenisnya tanpa syarat harus sama kadarnya (tamatsul), dan kelebihannya dijadikan sebagai kompensasi atas jasa pembuatan perhiasan, baik jual beli itu dengan pembayaran tunai maupun dengan pembayaran tangguh, selama perhiasan tersebut tidak dimaksudkan sebagai harga (uang) (Abdul Rahman, 2015). Ibnu Qayyim menjelaskan lebih lanjut, "perhiasan (dari emas atau perak) yang diperbolehkan, karena pembuatan (menjadi perhiasan) yang diperbolehkan, berubah statusnya menjadi jenis pakaian dan barang, bukan merupakan jenis harga (uang). Oleh karena itu, tidak wajib zakat atas perhiasan (yang terbuat dari emas atau perak) tersebut, dan tidak berlaku pula riba (dalam pertukaran atau jual beli) antara perhiasan dengan harga (uang), sebagaimana tidak berlaku riba (dalam pertukaran atau jual beli) antara harga (uang) dengan barang lainnya, meskipun bukan dari jenis yang sama. Hal itu karena dengan pembuatan (menjadi perhiasan) ini, perhiasan (dari emas) tersebut telah keluar dari tujuan sebagai harga (tidak lagi menjadi uang) dan bahkan telah dimaksudkan untuk perniagaan. Oleh karena itu, tidak ada larangan untuk memperjualbelikan perhiasan emas dengan jenis yang sama.

Imam Syafi'i berpendapat bahwasannya menjual atau tukar menukar emas dan perak dengan berbeda yang lain dengan kadar yang lebih banyak hukumnya boleh. Akan tetapi jika sesama emas dan perak maka tidak 
boleh, dengan kata lain perbuatan tersebut (emas dengan emas yang jumlahnya lebih banyak) merupakan riba. Untuk mensiasati hal tersebut, agar tidak menjadikan transaksi sesama emas masuk ke dalam riba Imam Syafi'i mensyaratkan agar transaksi emas dengan emas dilakukan dengan takkaran dan nilai yang sama, sebagai contoh emas lima gram dengan emas lima gram juga. Kemudian, mereka juga mensyaratkan dalam hal jual beli mata uang hendaknya dilakukan secara tunai, dan perbedaan pendapat dalam hal ini berkenaan dengan waktu yang membatasi transaksi. Imam Syafi'i dan Imam Hambali berpendapat bahwasannya transaksi jual beli mata uang secara tunai selama kedua belah pihak (penjual dan pembeli) belum berpisah, baik penerimaannya saat transaksi atau terlambat. Tetapi Imam Malik berpendapat jika penerimaannya terlambat maka jual beli tersebut hukumnya batal (tidak sah) meski penjual dan pembeli tersebut belum berpisah. Ibnu Khaldun berkata, Tuhan menciptakan dua logam mulia (emas dan perak) untuk menjadi alat pengukur nilai atau harga atas segala sesuatu (Ahmad Riawan, 2012). Al-Maqrizi dalam Ighatsah mengemukakan bahwasannya Tuhan menciptakan dua loga mulia bukan hanya untuk mengukur suatu nilai atau menyimpan kekayaan, akan tetapi ia juga berfungsi sebagai alat tukar (Ahmad Riawan, 2012).

\section{d) Implikasi bagi Kehidupan Ekonomi Kontemporer}

Rasulullah Saw telah mengajarkan etika bisnis, termasuk pemahaman tentang uang. Bagi ekonomi kapitalis di masa modern, uang merupakan komoditi yang dapat diperjualbeikan demi tujuan keuntungan (profit oriented) dengan perangkat bunga (Darmalaksana, 2018). Sementara itu, ekonomi Islam yang diajarkan Nabi Saw mengambil prinsip kesejahteraan (al-falah).

Menurut Wahyudin Darmalaksana, kehidupan di dunia tidak bisa dibantah dikendalikan oleh dua kekuatan (power) besar, yaitu aspek ekonomi dan aspek keimanan dalam agama. Kehidupan bidang ekonomi menjadi standar kehidupan suatu negara dan bangsa. Tidak dipungkiri bahwa keunggulan suatu negara jelas diukur berdasarkan tingkat kemajuan ekonomi mereka dan dengan demikian ukuran derajat keberhasilan dunia menjadi sangat ekonomis dan materialistik. Hanya saja belakangan ini muncul gejala dan fenomena baru yang menunjukan dimana kekuatan ekonomi tidak lagi berfokus pada kekuatan material saja, namun mengupayakan bagimana cara ilmu ekonomi tersebut bisa menyatu dengan kekuatan etika dan spiritual dari agama yang dikenal dengan integrative business ethic and spirituality. Dalam hal ini, menurut Wahyudin Darmalaksana, kalangan pakar sepakat, bahwa hanya sistem ekonomi yang berbasis etika dan moral inilah yang layak tampil dalam pengelolaan sistem ekonomi global sekarang ini. Kalangan pakar filsafat hukum Islam 
menyatakan, bahwa konsep integrative economic ethic hanya compatible dengan ekonomi Islam (Darmalaksana, 2018).

Pada dasarnya nilai uang dapat dilihat dari dua sudut pandang, yaitu nilai uang dilihat dari bahan pembuatannya dan dilihat dari penggunannya (Mishkin, 2008). Dilihat dari bahan pembuatannya, ada dua jenis. Pertama, nilai Instrinsik, yaitu nilai uang berdasarkan bahan-bahan pembuatan uang. Contohnya, untuk membuat uang logam Rp. 100 diperlukan logam perak sebesar 1 gram. Dengan demikian, uang sebesar Rp. 100 sama dengan harga yang senilai dengan 1 gram perak. Inilah yang disebut nilai instrinsik uang. Kedua, nilai Nominal, yaitu nilai yang tertera pada setiap mata uang yang bersangkutan. Pada uang Rp. 100.000 tertera angka seratus ribu rupiah, maka nilai nominal uang tersebut adalah seratus ribu rupiah.

Berdasarkan dua nilai di atas menimbulkan dua istilah fiduicer money dan full bodied money. Fiduicer money, yaitu uang yang memiliki nilai nominal lebih besar daripada nilai instrinsiknya. Contohnya ialah semua uang kertas. Adapun full bodied money, yaitu uang yang memiliki nilai nominal sama dengan nilai instrinsiknya. Contohnya ialah semua jenis mata uang logam sehingga uang logam disebut juga full bodied money.

Sejalan dengan pemahaman hadis, uang memiliki nilai esensial karenanya dibuat dalam logam mulia seperti emas dan perak. Ketika uang berubah menjadi uang kertas maka uang menjadi tidak memiliki esensial lagi. Orang hanya akan memiliki "kertas" di dalam sistem ekonomi kapitalis bila terjadi inflasi atau kerugian. Akan tetapi, orang tetap akan memiliki nilai yang berharga berupa logam mulia dalam wujud emas atau perak meskipun terjadi kehancuran ekonomi. Perubahan nilai uang dari logam mulia ke uang kertas lebih merupakan politik ekonomi dunia kapitalis (Darmalaksana, 2018). Implikasinya, ekonomi dunia Islam akan terus mengalami kekalahan karena tidak memiliki logam mulia. Sehingga perlu dipikirkan kembali di kehidupan ekonomi kontemporer ini menggembalikan sistem jual beli dengan menerapkan logam mulia. Suatu sistem ekonomi berbasis iman sebagaimana telah diajarkan dan dipraktikan oleh Rasulullah Saw. di dunia Islam.

\section{Kesimpulan}

Uang dapat dikatakan nuqud atau tsaman oleh masyarakat, baik yang terdiri dari logam atau kertas yang dicetak maupun dari bahan yang lainnya dan diterbitkan oleh lembaga keuangan pemegang otoritas. Uang yang digunakan oleh umat Islam pada masa Rasulullah adalah dirham perak Persia dan dinar emas Romawi dalam bentuk aslinya, tanpa mengalami pengubahan atau pemberian tanda tertentu. Setelah dilakukan kajian terhadap hadis-hadis tentang uang dengan metode syarah diketahui merupakan hadis maqbul dan dapat dijadikan hujjah. Pemahaman hadishadis tentang uang berkenaan dengan jual beli dan riba adalah langkah 
agar jual beli jangan berlebihan dan untuk menutup kemungkinan dari praktek riba. Pelarangan riba secara efektif akan mengendalikan inflasi sehingga daya beli masyarakat terjaga dan stabilitas perekonomian tercipta. Ekonomi Islam lebih ditekankan pada suatu konsep dan usaha untuk dapat meningkatkan kesejahteraan masyarakat. Dengan demikian, ekonomi Islam adalah jawaban tantangan peradaban dunia. Dari pemahaman hadis tentang nilai uang ini terdapat implikasi dimana perlu dipikirkan ulang di kehidupan ekonomi kontemporer dalam penggunaan logam mulai bagi praktik jual beli, paling tidak mesti menjadi renungan bagaimana dunia Islam tidak selalu dikalahkan oleh politik uang ideologi kapitalisme. Penelitian ini diharapkan memiliki implikasi manfaat bagi pengembang hazanah pengetahuan Islam khususnya dalam bidang kajian hadis. Diakui penelitian ini memiliki keterbatasan dalam pelaksanaan syarah hadis dengan pendekatan tematik ini sehinga diperlukan penelitian lebih lanjut secara komprehensif, integral dan mendalam. Penelitian ini merekomendasikan diadakannya penelitian yang lebih mendalam terutama bagi para pengkaji hadis tentang nilai uang dengan pendekatan keilmuan lain yang akan membuka pemahaman yang lebih luas mengenai topik ini.

\section{Daftar Pustaka}

Abdulloh, Rich, \& Laode, M. K. (2011). Meneladani Kepemimpinan Bisnis Rasulullah. Jakarta: Ihwah Publishing House.

Abdurrahman, A. B. (2010). Taisirul Allam Syarah 'Umdatul Ahkam, terj. Fathul Mujib, Taisirul 'Allam Syarhu Umdatil Ahkam. Malang: Cahaya Tauhid Press.

Ahmad Riawan, A. (2012). Satanic Finance. Jakarta: PT. Ufuk Publishing House.

al-Mubarakfuri. (1967). Tuhfat al-Ahzawi Syarh Jami at-Turmuzi Juz V. Madinah: Muhsin al-kutubi.

al-Qattan, M. (2005). Mubahis fi' Ulumul Hadis. Kairo: Maktabah wahbah.

an- Nabhani, T. (1999). Membangun Sistem Ekonomi Alternatif Perspektif Islam. Surabaya: Penerbit Risalah Gusti.

Andri, S. (2009). Bank dan Lembaga Keuangan Syariah. Jakarta: Kencana Prenada Media Group.

Anita, R. (2013). Uang dan Kebijakan Moneter dalam Perspektif Ekonomi Islam. Kudus: STAIN Kudus.

an-Nabhani, T. (2000). Membangun sistem ekonomju Alternatif perspektif Islam. Surabaya: Risalah Gusti.

Arifin, Z. (2003). Dasar - dasar Manajemen Bank Syari'ah. Jakarta: Penerbit Alvabet.

Ayub, M. (2009). Understanding Islamic Finance: A-Z Keuangan Syariah. Jakarta: Gramedia Pustaka Utama. 
Budiantoro, R. A., Sasmita, R. N., \& Widiastuti, T. (2018). Sistem Ekonomi (Islam) dan Pelarangan Riba dalam Perspektif Historis. Jurnal Ilmiah Ekonomi Islam, 4(01), 1-13.

Bustaman, B. (2016). Konsep Uang dan Peranannya dalam Sistem Perekonomian Islam (Studi Atas Pemikiran Muhammad Abdul Mannan) (Doctoral dissertation, Universitas Islam Negeri Alauddin Makassar).

Darmalaksana, W. (2018). Asas konkorDansi Islam Dan pancasila bagi perkembangan perbankan syariah di indonesia. Epistemé: Jurnal Pengembangan Ilmu Keislaman, 13(1), 195-229.

Darmalaksana, W. (2018). Filsafat dan Politik Hukum Islam tentang Perbankan Syariah: Kajian Filsafat dan Politik Hukum Islam bagi Perkembangan Perbankan Syariah di Indonesia. Bandung: Pascasarjana UIN Sunan Gunung Djati Bandung.

Darmalaksana, W. (2020). Cara Menulis Proposal Penelitian. Bandung: Fakultas Ushuluddin UIN Sunan Gunung Djati Bandung.

Darmalaksana, W. (2020). Kelas Menulis dari Proposal Ke Artikel Ilmiah, Publikasi Jurnak dan Hak Kekayaan Intelektual. Bandung: Sentra Publikasi Indonesia.

Darmalaksana, W. (2020). Penelitian Metode Syarah Hadis Pendekatan Kontemporer: Sebuah Panduan Skripsi, Tesis, dan Disertasi. Diroyah: Jurnal Studi Ilmu Hadis, 5(1), 58-68.

Dimyati, A. (2008). Teori keuangan islam rekonstruksi metodologi terhadap keuangan Al-Ghazali. Yogyakarta: UII Press.

Fadilla, F. (2019). Sejarah Penggunaan Uang Sejak Masa Rasulullah SAW Sampai Sekarang. Islamic Banking: Jurnal Pemikiran dan Pengembangan Perbankan Syariah, 4(2), 97-106.

Faridha, N. N. (2011). Studi Komparasi Konsep Uang Dalam Sistem Ekonomi Kapitalis Dan Sistem Ekonomi Islam. Maliyah: Jurnal Hukum Bisnis Islam, 1(1).

Hasan, A. (2005). Mata Uang Islami: Telaah Komprehensif Sistem Keuangan Islami. Jakarta: PT.Raja Grafindo Persada.

Hasibun, M. S. (2001). Dasar-dasar Perbankan. Jakarta: Penerbit PT. Bumi Aksara.

Ichsan, M. (2020). Konsep Uang Dalam Perspektif Ekonomi Islam. Profetika: Jurnal Studi Islam, 21(1), 27-38.Ilyas, R. (2016). Konsep Uang dalam Perspektif Ekonomi Islam. Jurnal Bisnis dan Manajemen Islam.

Irawan, P., \& Dkk. (2009). Metode Penelitian. Bandung: Universitas Terbuka. Juliana, J. (2017). Uang dalam Pandangan Islam: Kritik terhadap Konsep Grasham. Amwaluna: Jurnal Ekonomi dan Keuangan Syariah, 1(2), 217230.

Karim, A. (2005). Bank dan Lembaga Keuangan Lainnya. Jakarta : PT Grafindo Persada.

Karim, A. A. (2001). Ekonomi Islam. Jakarta: Gema Insan Press. 
Latifah, N. A. (2015). Kebijakan Moneter dalam Perspektif Ekonomi Syariah. Jurnal Ekonomi Modernisasi, 11(2), 124-134.

Saleh, L. (2016). Perubahan Nilai Tukar Uang Menurut Perspektif Ekonomi Islam. Li Falah: Jurnal Studi Ekonomi dan Bisnis Islam, 1(1), 68-79.

Misbahul, M. (2016). Analisis Tematik terhadap Konsep Uang. Malang: UIN Maulana Malik Ibrahim Malang.

Mishkin, F. S. (2008). The Economic of Money, Banking, and Financial Markets. New York : Fourth Edition, Person Education Inc. new Jersey.

Mujahidin, A. (2007). Ekonomi Islam. Bekasi. PT Raja Grafindo Persada.

Mujibatun, S. (2012). Konsep Uang dalam Hadis. Semarang : IAIN Walingoso.

Pertadireja. (1994). Pengantar Ekonomika. Yogyakarta: BPFE.

Presetyo, A. (2017). Peran Uang dalam Sistem Moneter Islam. Majalah Ekonomi, 22(1), 104-110.

Qomarullah, M. (2016). Metode Takhrij Hadits Dalam Menakar Hadits Nabi. El-Ghiroh: Jurnal Studi Keislaman, 11(2), 23-34.

Ramli, A. R. (2015). Jual Beli Emas Secara Tidak Tunai (Telaah Fatwa DSN-MUI No. 77/DSN-MUI/V/2010) (Doctoral dissertation, Universitas Muhammadiyah Surakarta).

Rozalinda. (2014). Ekonomi Islam: Teori dan Aplikasinya pada Aktivitas Ekonomi. Bekasi: PT Raja Grafindo Persada.

Saeed, A. (1996). Islamic banking and interest: A study of the prohibition of riba and its contemporary interpretation (Vol. 2). Brill.

Sanusi, A. (2014). Takhrij Hadis. Depok: Madani Publishing.

Shan'ani, A. (1995). Terjemahann Subulussalam, Jilid III, Terj. Abu Bakar Muhammad, Subulussalam III. Surabaya: Al-Ikhlas .

Siti, M. (2012). Konsep Uang dalam Hadis. Semarang: Lembaga Studi Sosial dan Agama (eLSA).

Siti, M. (2012). Konsep Uang dalam Islam. Semarang: Lembaga Studi Sosial dan Agama (eLSA).

Soetari, E. (2015). Syarah dan Kritik Hadis dengan Metode Tahrij: Teori dan Aplikasi. Bandung: Yayasan Amal Bakti Gombong.

Sukardi. (2011). Metodologi Penlitian Pendidikan Kompetensi dan Praktiknya. Jakarta: Bumi Aksara.

Suqiyah, M. (2007). Hadis Hukum Ekonomi Islam. Surabaya : Government of Indonesia (GoI) dan Islamic Development.

Suryadialaga, A. (2012). Metode Syarah Hadis. Yogyakarta: Suka Press.

Susanti, R. (2018). Sejarah Transformasi Uang Dalam Islam. Aqlam: Journal of Islam and Plurality, 2(1).

Wiyono, A. H. (2020). Kajian Tahrij Hadits dalam Studi Islam. SAMAWAT, 3(2).

Yamani, M. T. (2015). Memahami Al-Qur'an dengan metode tafsir maudhu'i. J-PAI: Jurnal Pendidikan Agama Islam, 1(2). 